Nig. J. Biotech. Vol. 36(2): 1 - 8 (Dec 2019)

ISSN: 01891731

Available online at

http://www.ajol.info/index.php/njb/index

and www.biotechsocietynigeria.org

DOI: https://dx.doi.org/10.4314/njb.v36i2.1

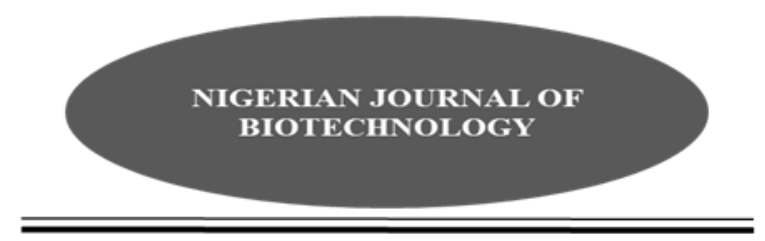

\title{
Value of Seed Protein Profile in the Taxonomy of cultivars of Capsicum in Nigeria.
}

\author{
1* Adepoju, A.O., ${ }^{2}$ Ogunkunle, A.T.J., ${ }^{2}$ Azeez, M.A. and ${ }^{3}$ Femi-Adepoju, \\ A.G \\ ${ }^{* 1}$ Dept. of Biological Sciences, Fourah Bay College, University of Sierra Leone, Freetown, Sierra Leone; \\ ${ }^{2}$ Dept. of Pure and Applied Biology, Ladoke Akintola University of Technology, Ogbomoso, Nigeria; \\ ${ }^{3}$ Department of Plant and Environmental sciences, Kwara State University, Malete. Nigeria
}

\begin{abstract}
:
Over a decade, the taxonomy of the genus Capsicum in Nigeria has remained largely unrevised, unclassified and unidentified. As such, there is a dearth of information on the proper identification of Capsicum spp and relatives found in the country. The aim of this study was to re-examine the taxonomic status of the Capsicum in Nigeria in order to establish genetic diversity between them for proper identification and classification. Sodium dodecyl polyacrylamide gel electrophoresis of total seed protein was performed on five varieties of Nigerian Capsicum spp., following standard procedures. Six protein bands were observed across the five cultivars of Capsicum, of which 12-14 Kda was the only polymorphic band. Only $C$. fructescens var. ijosi and $C$. fructescens var. sombo were unique for manifesting 20-24 and 15-16 Kda bands respectively. Dendrogram of analysis obtained resolved the taxa into two distinct groups. In the first group were cultivars of $C$. fructescens var. ijosi and sombo while in the second group were $C$. chinense, which was distinctly separated from $C$. fructescens var. bawa and $C$. annum. Artificial dichotomous key was constructed for the identification of members of the genus Capsicum available in Nigeria based on the protein profiles of their seeds.
\end{abstract}

Keywords: Capsicum, seed protein, electrophoresis, identification, diversity.

Corresponding author e-mail: mryinkaadepoju@gmail.com, Tel: +2348030532573

\section{Introduction}

In West Africa, peppers are widely grown and are used in a number of ways. They occupy third position in Nigeria among the cultivated vegetables being utilized in the dry state as spice due to their capsaicin content (an alkaloid which is a digestive stimulant) and as vegetable, when supplied for their vitamin content and aroma (USDA, 2015). The crop is utilized both as condiment and food. The thick sweet fleshy or non-pungent varieties are used in salads or stuffed with meat and cooked (Arnarson, 2015). The chemical in chilli peppers (i.e. Capsicum) responsible for the burning sensation is capsaicin which affects only mammals, but not birds. Capsaicin extract is used to make pepper spray, a useful deterrent against aggressive mammals (Grubben and El Tahir, 2004). Pepper fruit accounts for a large portion of vitamins $A$ and $C$ in many Nigerian diets; the most common species of pepper in Nigeria are Capsicum annum L., C. chinense 
Jaqc. and Capsicum frutescens $\mathrm{L}$. (DeWitt and Bosland, 2009).

The genus Capsicum in Nigeria has not been thoroughly revised, identified and classified. There is therefore a dearth of information on the exact number of Capsicum spp and varieties found in the country. In addition, some reported works on Nigerian Capsicum misrepresented some Capsicum species due to lack of proper identification. For instance, Aziagba et. al., (2014), erroneously assigned the local name 'shombo' (Yoruba name for a cultivar of $C$. fructescens) to $C$. annuum and 'atarugu' (Hausa name for $C$. chinense) to C. annuum. When the classification of taxa is confused, so is the nomenclature and literally, any information about such taxa is not specific and therefore, less useful. Capsicum has long been regarded as a taxonomically difficult genus by many workers (Pickersgill et. al., 1979; Eshbaugh, 1970, 1975, 1980; Heiser and Pickersgill, 1975; Edeoga et. al., 2010; Zhigila et. al., 2014). In fact, there is no agreement yet among workers with regard to the number of species of Capsicum present in Nigeria.

Presently, there is no satisfactory revision of the taxonomical status of the Nigerian genera of Capsicum. . Moreso, some species of the genus being considered in this study (i.e. Capsicum) are difficult to distinguish because members of the genus have been reported to possess morphological similarities and some are highly phenotypically plastic (Moscone et. al., 2007; Walsh and Hoot, 2001). So far, only one report (Olatunji and Morakinyo, 2015) could be traced on taxonomic markers based on biochemical contents or SDS-PAGE analysis with respect Capsicum species and varieties in Nigeria. Olatunji and Morakinyo (2015) claimed to have worked on $C$. fructescens and C. annuum varieties only, leaving out $C$. chinense, which is a commonly used variety in Nigeria. The results of their study also indicated some levels of confusion, as there were reports of consistencies between the protein profile from the leaves when compared with those of the seeds, in their study. These problems clearly justify the necessity for a proper identification of all members of the Nigerian Capsicum taxon by their seed protein composition, especially because a preliminary survey of the wild and cultivated Nigerian species of the Capsicum genus revealed several cases of confusion regarding uncertainty in names and genetic distances.

The aim of this study was to evaluate the seed proteins of the plant species using Sodium Dodecyl Polyacrylamide Gel Electrophoresis (SDS PAGE) with a view to establish genetic diversity between species and also document those protein markers that could be utilized for diagnosing the varieties and species of Capsicum in Nigeria.

\section{Materials and Methods}

\section{Sample Collection and regeneration:}

Seeds of the Nigerian species of Capsicum investigated were collected from cultivated field, identified with the assistance of Prof. H.C. Illoh at Obafemi Awolowo University Herbarium (OAUH) and thereafter grown (for the purpose of a balance in environmental conditions) at the Botanical garden, Ladoke Akintola University of Technology, Ogbomoso. The seeds obtained from the regenerated plants were used as material for Sodium Dodecyl Sulfate Polyacrylamide Gel Electrophoresis (SDS-PAGE) analysis which was carried out at the Molecular Biology and Biotechnology department, Nigerian Institute of Medical Research (NIMR), Yaba, Lagos.

\section{Protein extraction}

About 200mg seeds from each genotype was homogenized with mortar and pestle using $0.01 \mathrm{M}$ Tris-Hcl buffer ( $\mathrm{pH}$ 7.5). The resulting homogenates were centrifuged at $15000 \mathrm{rpm}$ for 10 minutes, the supernatants were filtered with 541 Whatmann filter paper. The residues were boiled at $90^{\circ} \mathrm{C}$ for five minutes with $1: 1$ ratio of $1.0 \mathrm{M}$ Tris ( $\mathrm{pH}$ 6.8), 10\% SDS; $2 \% \quad \beta-$ mercaptoethanol, $10 \%$ glycerol and $0.002 \%$ bromophenol blue (following the method of Kumar and Tata (2010) with gel composition as indicated in Table 1.

\section{Electrophoresis}

SDS-PAGE of total seed protein was carried out in vertical slab gel in discontinuous 
buffer system following the method that was modified by Essiet and Illoh (2008) as follows: On cooling to room temperature, three drops of $10 \%$ Sodium dodecyl sulfate (SDS), $1 \%$ of 2 mercaptoethanol and sucrose crystals was added to the sample in order to weigh down the protein molecules. Then, one drop of $0.05 \%$ bromophenol which served as a tracer dye was added. Four drops of the resultant mixture

Table 1: Gel Composition adopted for SDS-PAGE in the study. obtained from the product was directly added to the gels. The tubes were then placed in column acrylamide gel apparatus with tri-glycine buffer in both the upper and the lower vessels. A current of $1.5 \mathrm{~mA}$ per gel was applied. The current was thereafter increased to $3 \mathrm{~mA}$ per gel until the dye front was $1 \mathrm{~cm}$ from the bottom of the gel.

\begin{tabular}{lll}
\hline Chemical & Upper Gel $\mathbf{( \mathbf { c m } ^ { 3 } )}$ & Lower $\mathbf{G e l}\left(\mathbf{c m}^{\mathbf{3}}\right)$ \\
\hline Acrylamide A. & 1.35 & 13.53 \\
Upper gel buffer (4x) & 2.50 & - \\
Lower gel buffer (4x) & - & 7.50 \\
Distilled water & 6.00 & 8.57 \\
10\% Sodium Dodecyl Sulphate (SDS) & 0.10 & 0.30 \\
Ammonium per Sulphate & 0.10 & 0.30 \\
TEMED & 0.01 & 0.03
\end{tabular}

Source: Essiet and Illoh (2008).

\section{Staining and destaining}

After electrophoresis, the gels were stained with Coomassie Brilliant Blue (R250) for 30-40 minutes with continuous shaking, then shifted to another container with destaining solution of methanol and acetic acid for 45 minutes. The gels were further de-stained until the back ground was clear enough for bands scoring. Marker proteins (RPMW): Bovine Serum Albumin (66 kilodaltons), Egg Ovalbumin (45 kilodaltons), Pepsin Porcine Stomach Mucosa (34.7 kilodaltons). Bovine Trypsinogen (24 kilodaltons) and B- Lactoglobulin (18.4 kilodaltons) were used as references. Protein marker used was in form of "MW-SDS-70 Kit" from Sigma Chemical Company, USA. Molecular weights of protein bands were estimated by their relative mobilities. In order to eliminate differences in electrophoretic conditions as a cause of variation in the protein profiles, each genotype protein sample was separated from three independent electrophoretic runs and two separate extractions (Kumar and Tata, 2010). In analyzing the data obtained, presence of a band was scored " 1 " while absence of the band was scored " 0 " to generate binary matrix which was used to perform statistical analysis.

\section{Cluster Analyses}

The scores of the protein fragment in relative to the standard marker were used as characters to perform a cluster analysis on the species; each of which was taken as operational taxonomic units (OTU). Dendrograms were obtained by adopting a hierarchical cluster analysis using Ward's method applying squared Euclidean Distance (as the distance or similarity measure), both of which could be combined using PAST (Paleontological Statistics Software Package) by Hammer et. al. (2001).

Construction of Dendrogram and Artificial key An artificial dichotomous key was constructed for the purpose of diagnosing the species in each genus, using the characters obtained. While the qualitative characters were directly 
used, as observed, the means of quantitative characters were first subjected to statistical significance across the species in each genus to determine which ones were truly diagnostic. The statistical tool used for dendrogram construction was SPSS version 21.

\section{Results}

The results of SDS PAGE analysis of the seed proteins in the plants studied are shown in Plate 1 and Table 2. A total of six protein bands was observed across the five cultivars of Capsicum i.e. B1, B2, B3, B4, B5 and B6. The molecular weight of the protein were $35 \mathrm{kDa}, 28-32 \mathrm{kDa}$,
25-27 kDa, 20-24 kda, 15-16 kda and 12-14 kda respectively (Table 2 ).

Among these bands, $12-14 \mathrm{kda}$ is the polymorphic band for the Capsicum species as all the taxa contained the protein with that range of marker. The $35 \mathrm{kda}$ band was present in only $C$. fructescens (var. bawa) and $C$. annuum; 28-32 kDa band was found in only $C$. fructescens (var. ijosi and var. sombo); 25-27 Kda band was observed in two varieties of $C$. fructescens (i.e. sombo, bawa and in $C$. annuum; 20-24 Kda band was discovered only in C. fructescens var. ijosi while the $15-16 \mathrm{Kda}$ band was observed in all but $C$. fructescens var. sombo.

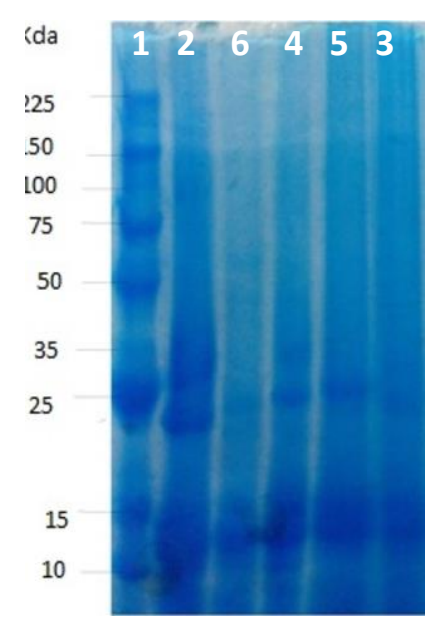

Plate 1: Plate 4.13: SDS-PAGE Gel electrophoresis analysis of seed protein of five cultivars of Capsicum in Nigeria. (1=Protein Markers, $2=C$. fructescens var. ijosi, $3=C$. fructescens var sombo, $4=C$. fructescens var bawa, $5=C$. annuum, $6=C$. chinense).

Table 2: SDS PAGE Score of seed protein contents in the Capsicum spp studied.

\begin{tabular}{c|cccccc}
\hline Taxa & \multicolumn{7}{c}{ Bands (kDa) } & & 15-14 \\
\hline IJO & $\mathbf{3 5}$ & $\mathbf{2 8 - 3 2}$ & $\mathbf{2 5 - 2 7}$ & $\mathbf{2 0 - 2 4}$ & $\mathbf{1 5 - 1 6}$ & $\mathbf{1 2 - 1 4}$ \\
SOM & 0 & 1 & 0 & 1 & 1 & 1 \\
BAW & 0 & 1 & 1 & 0 & 0 & 1 \\
ANN & 1 & 0 & 1 & 0 & 1 & 1 \\
CHI & 0 & 0 & 1 & 0 & 1 & 1 \\
\hline
\end{tabular}


$0=$ absent; $1=$ present. $(\mathrm{IJO}=C$. fructescens var. ijosi, $\mathrm{SOM}=C$. fructescens var. sombo, $\mathrm{BAW}=C$. fructescens var. bawa, $\mathrm{ANN}=C$. annuum and $\mathrm{CHI}=C$. chinense).

The dendrogram which was constructed based on the UPGMA shows distinct separation of the Nigerian varieties of Capsicum in Nigeria into two major groups (HC and LC) at $23 \%$ genetic distance. Among the two major clusters obtained, the higher cluster $(\mathrm{HC})$ has $C$. fructescens var. ijosi and C. fructescens var. sombo at $13 \%$ genetic distance while the lower cluster (LC) consists of two sub-clusters (LC1 and $\mathrm{LC} 2$ ) at $11 \%$ distance. LC1 (occurring at $11 \%$ distance) consists of $\mathrm{C}$. chinense while LC2 consists of $C$. fructescens var. bawa and $C$. annuum.

\section{Discussion}

In consonance with the results obtained from morphological, leaf epidermal and wood anatomical evaluation of the cultivars of Capsicum (Adepoju, 2018), the dendrogram obtained from seed protein data (Fig 1) resolved the taxa into three distinct groups. In the first group were two cultivars of $C$. fructescens clustered (i.e. varieties ijosi and sombo); in the second, C. fructescens var bawa and $C$. annuum clustered; while $C$. chinense stood as a distinct cluster on its own.
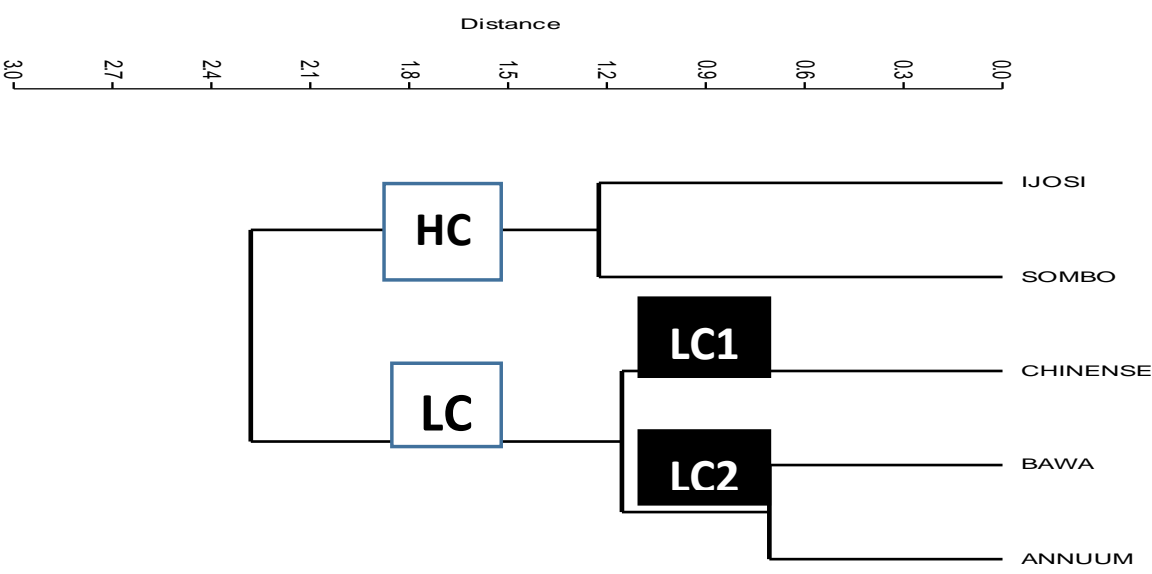

Fig 1: Dendrogram based on the cluster Analysis of seed protein data recorded on the five Nigerian cultivars of Capsicum studied (IJOSI $=$ C. fructescens var. ijosi, $\mathrm{SOMBO}=C$. fructescens var. sombo, $\mathrm{BAWA}=C$. fructescens var. bawa, $\mathrm{ANNUUM}=C$. annuum and $\mathrm{CHINENSE}=C$. chinense) .

Biosystematic Implications of the seed protein molecular weights observed in Capsicum

It is clear that the dendrogram in Fig 1 , and those obtained from morpholo! ' ' ' epidermal data of these Capsicu

Adepoju (2018) are similar in all respects, indicating that the classificatory value of morphological, leaf epidermal and seed protein characters in this genus are the same. Also, if one places the dendrogram obtained by Adepoju (2018) for wood anatomical characters of the cultivars side by side with Fig 1 , one finds out some similarity between the two, particularly as regards the close clustering of $C$. fructescens var. bawa and C. annuum.
Again, the results as depicted in Figure 1 closely align with capsaicin content profile of the fruits of these plants (Nwokem et. al., 2010 and Zeid et. al., 2011). In the first place, the two cultivars with low fruit capsaicin contents clustered together (i.e. C. fructescens var. bawa and $C$. annuum) while the two cultivars of $C$. fructescens with high content of this chemical (i.e. var. ijosi and var. sombo) clustered as a group. Lastly, $C$. chinense which is acknowledged to possess an intermediate value of capsaicin content between the two extremes stood alone as a cluster between the earlier two groups (Fig 1). 
McLeod et. al. (1982) reported a close distance of clustering between $C$. chinense and the two varieties of $C$. fructescens and the present study agreed with the authors report. Also, Bhat and Kudesia (2011) studied the protein profile of 5 species of the family Solanaceae (i.e. Solanum melongena, $S$. xanthocarpum, Datura alba, Lycopersicon esculentum and Capsicum annum) using SDSpoly acrylamide gel electrophoresis. Their results revealed that the genus Lycopersicon was very close to the genus Solanum and that the species Datura alba and Solanum melongena were closer at molecular level compared to other species. Furthermore, similarity index was higher for Capsicum annum and Solanum xanthocarpum (22.22\%) which are cultivated and wild types respectively, as compared to two exclusively wild species of Datura alba and Solanum xanthocarpum (in which their similarity index was only $11.11 \%$ ). Yousaf et. al., (2006) also investigated the taxonomical status of 42 accessions belonging to 7 species of 4 different genera (Datura, Hyoscyamus, Withania and Atropa) from the family Solanaceae by Poly Acrylamide Gel Electrophoresis. A dendrogram constructed based on UPGMA revealed the generic status and inter relationship of Hyoscyamus, Atropa, Withania and Datura. The specimens of Withania somnifera collected from Panjgur (109717, 109718, and 109710) did not only show their morphological variation but also, variations based on their protein profiles. Based on the total seed protein profiles, close association was noticed by between Withania/Datura and Atropa/Hyoscyamaus but they maintained their generic status, as there was no species intermixing.

Olatunji and Morakinyo (2015) carried out SDS-PAGE of leaf and seed protein in four Nigerian Capsicum varieties. Their results showed distinct electrophoretic banding patterns with a total of 38 bands. They concluded based on the results of their work that the differences and similarities observed in the protein profiles among the Capsicum species studied were indicative of genetic diversity, that Electrophoresis (SDS-PAGE) of seed and leaf proteins can be used as effective technique in plant characterization, identification and differentiation, would be of importance for broadening the Capsicum gene pool and that it may be used in hybridization in breeding programmes.

From the foregoing account, it can be said that analysis of seed protein profiles have been useful for resolving ambiguous taxonomic boundaries in the genus Capsicum. Moreover, these data have sufficient diagnostic potential among the five cultivars of the Nigerian Capsicum studied as evident from the entries in Tables 3 and 4.

In Capsicum, the seed protein profile has similar classificatory value in line with only those clusters based on fruit capsaicin content. This study has established for the first time, some concordance between fruit capsaicin content (or fruit hotness) in Capsicum and infrageneric taxonomic groupings based on such conventional characterization approach, as seed protein profile. Variations in seed protein profile on Nigerian species of Capsicum have been documented in form of unambiguous artificial keys for proper identification of the species.

Table 3: A Numerical key on seed protein profile for identification of five cultivars of Capsicum in Nigeria.

\begin{tabular}{cccccc}
\hline TAXA & $\mathbf{1}(35 \mathrm{kDa})$ & $\mathbf{2}(28-32 \mathrm{kDa})$ & $\mathbf{3}(25-27 \mathrm{kDa})$ & $\mathbf{4}(20-24 \mathrm{kDa})$ & $\mathbf{5}(15-16 \mathrm{kDa})$ \\
\hline IJO & 0 & 2 & 0 & 4 & 5 \\
SOM & 0 & 2 & 3 & 0 & 0 \\
BAW & 1 & 0 & 3 & 0 & 5 \\
ANN & 0 & 0 & 3 & 0 & 5 \\
\hline
\end{tabular}




$\begin{array}{llllll}\text { CHI } & 1 & 0 & 0 & 0 & 5\end{array}$

$(\mathrm{IJO}=C$. fructescens var. ijosi, $\mathrm{SOM}=C$. fructescens var. sombo, $\mathrm{BAW}=C$. fructescens var. bawa, $\mathrm{ANN}=C$. annuum and $\mathrm{CHI}=C$. chinense $)$.

Table 4: A seed protein-based dichotomous key for identification of five cultivars of Capsicum in Nigeria.

1a. Protein bands $28-32$ kda molecular weight detected in seed

2a. Protein Bands 20-24 and 15-16 present in plant seed C. fructescens. var. ijosi

2b. Protein Bands 20-24 and 15-16 absent in plant seed C. fructescens. var. sombo

1b. Protein bands of 28-32 kda molecular weight not detected in seed .3

3a. 25-27 kda band of seed protein detectable 4

4a. 35kda protein band discovered in plant seed C. fructescens. var. bawa

4b. 35kda protein band discovered in plant seed C. annuum

3b. 25-27 kda band of seed protein not detectable C. chinense

In conclusion, out of the six seed protein bands observed in Capsicum, the band with the molecular weight of $12-14 \mathrm{kda}$ was polymorphic in Capsicum. Also, the seed protein profile has similar classificatory value in line with only those clusters based on fruit capsaicin content.

\section{Acknowledgements}

The authors are grateful to Senate Research Council, Ladoke Akintola University of Technology, Ogbomoso (LAURESCON), Nigeria for providing financial assistance on this work and to Dr. Gloria Barboza of Instituto Multidisciplinario de Biología Vegetal, Córdoba, Argentina for providing some useful insights into the taxonomy of Capsicum.

\section{References}

Adepoju, A.O. (2018). Biosystematic Studies of Capsicum L. and Solanum L. in Nigeria. PhD thesis, submitted to Department of Pure and Applied Biology, Ladoke Akintola University of Technology, Ogbomoso, Nigeria. Pp 488.

Arnarson, A. (2015). Bell Peppers 101: Nutrition Facts and Health Benefits. http://authoritynutrition.com/foods/bellpeppers/ Retrieved on 20 2015.

Aziagba, B.O., Okeke, C.U., Ezeabara C.A., Uka C.J. and Egboka, T.P. (2014). Transverse section of the root of Capsicum species and their taxonomic importance. J. Pl. Sci. 2014; 2(5): 222-225. doi: 10.11648/j.jps.20140205.21.

Bhat, T.M. and Kudesia, R. (2011). Evaluation of Genetic Diversity in Five Different Species of Family Solanaceae, using Cytological Characters and Protein Profiling. Gen. Eng. Biotec. J., 2011: 1-8.

DeWitt, D. and Bosland, P.W. (2009). The Complete Chile Pepper Book: A Gardener's Guide to Choosing, Growing, Preserving, and Cooking. Timber Press City.

Edeoga, H.O., Omosun, G.O. and ThankGod, L.I. (2010). Exomorphology of Leaf Epidermis of some Nigerian Capsicum (Solanaceae). 4: 087090.

Eshbaugh, W.H. (1970). A biosystematic and evolution study of Capsicum baccatum (Solanaceae), Brittonia, 22: 31-43. 
Eshbaugh, W.H. (1975). Genetic and Biochemical Systematic Studies of Chilli Peppers (Capsicum-Solanaceae). Bull. Torrey Bot. Club. 102: 396-403.

Eshbaugh, W. H. (1980). The Taxonomy of the Genus Capsicum (Solanaceae). Phytologia, 47(3): 154-166.

Essiett, U.A. and Illoh, H.C. (2008). Crude Protein Electrophoresis of Seed of Ten Species of Solanum L. Global J. Pure Appl. Sci. 14 (3): 532.

Grubben, G.J.H. and El-Tahir I.M. (2004). Capsicum annuum L. In: Grubben, G.J.H. \& Denton, O.A. (Editors). PROTA 2: Vegetables/Légumes. [CD-Rom]. PROTA, Wageningen, Netherlands.

Hammer, Ø., Harper, D.A.T., and Ryan, P. D. (2001). PAST: Paleontological Statistics Software Package for Education and Data Analysis. Palaeontologia Electronica 4(1): 1-9.

Heiser, C.B. Jnr. and Pickersgill, B. (1975). Name for the bird peppers (CapsicumSolanaceae). Baileya, 19: 151-156.

Kumar, O.A. and Tata, S.S. (2010). SDS-Page Seed Storage Protein Profiles in Chili Peppers (Capsicum L.). Not Sci Biol. 2(3): 86-90.

McLeod, M.J., Guttman, S.I. and Eshbaugh, W.H. (1982). Early evolution of chili peppers; (Capsicum). Econ. Bot. 36: 361- 368.

Moscone, E.A., Scaldaferro, M.A., Gabriele, M., Cecchini, N.M., Sánchez-García, Y., Daviña, J.R., Ducasse, D.A., Barboza, G.E. and Ehrendorfer, F. (2007). The evolution in chili peppers (Capsicum-Solanaceae), a cytogenetic perspective. Acta Horticulturae (ISHS) 745: 137170.

http://www.actahort.org/books/745/745_5.htm.

Nwokem, C.O., Agbaji, E.B., Kagbu, J.A. and Ekanem, E.J. (2010). Determination of Capsaicin Content and Pungency Level of Five Different Peppers Grown in Nigeria. New York Sci. J. 3(9): 17-21
Olatunji T.L. and Morakinyo J.A. (2015). Crude Protein Profiling of Varieties of Capsicum annuum and Capsicum frutescens using SDSPAGE. IOSR Journal of Pharmacy and Biological Sciences. 10(3): 64-71.

Pickersgill, B., Heiser, C.B. and McNeill, J. (1979). Numerical Taxonomic Studies on Variation and Domestication in some Species of Capsicum. In: J.G. Hawkes, R.N. Lester and A.D. Skelding (eds.), The Biology and Taxonomy of the Solanaceae. Linn. Soc. Symp. Ser., Academic Press, London, UK. 7: 679-700.

USDA (United States Department of Agriculture), ARS (Agricultural Research Service), National Genetic Resources Program. Germplasm

Resources Information Network - (GRIN) [Online Database]. (2015). National Germplasm Resources Laboratory, Beltsville, Maryland. Solanaceae. URL: http://www.ars-grin.gov.4/cgibin/npgs/html/splist.pl?19061 (Retrieved 12 July 2015).

Walsh, B.M. and Hoot, S.B. (2001). Phylogenetic relationships of Capsicum (Solanaceae) using DNA sequences from two noncoding regions: the chloroplast atpB-rbcL spacer region and nuclear waxy introns. Int. J. Plt. Sci., 162: 14091418.

Yousaf, Z., Shahid M., Zabta K. S., Mir A. K. and Ashiq R., (2006). Evaluation of Taxonomic Status of Medicinal Species of the genus Solanum and Capsicum based on Poly Acrylamide Gel Electrophoresis. Pak. J. Bot., 38(1): 99-106.

Zeid, A.A., Yacine, B.H., Mohamed A.H., and Ayman A.G. (2011) Determination of Capsaicin and Dihydrocapsaicin in Capsicum fruit samples using High Performance Liquid Chromatography. Mol. 16(10): 8919-8929. doi: $10.3390 /$ molecules 16108919

Zhigila D.A., AbdulRahaman A.A., Kolawole O.S, and Oladele F.A. (2014). Fruit Morphology as Taxonomic Features in Five Varieties of Capsicum annuum L. Solanaceae.

J. Bot. Article ID: 540868, 6 pages. http://dx.doi.org/10.1155/2014/540868. 